\title{
Nursing education in Sweden: Recruitment from different socioeconomic backgrounds
}

\section{Karin Anna Petersen, lektor, docent, professor (gäst) Sverker Lundin, doktorand}

ABSTRACT:

A study mainly based on national register of all student in higher education during 1997-2001. Focus is on educations towards health and nursing as part of a social field of higher education

(Bourdieu).

Quite contrary to being a resource for achieving higher status, we tentatively claim that the

title as a nurse also make the relation of domination towards medicine more clear cut and therefore contributes to its reproduc-

tion.

KEYWORDS: Nursing, Medicine, Recruitment, Social background, Education, Bourdieu

\section{Introduction}

The article is written as a part of a Swedish research project OMOM, www.ped.uu.se/omom. It is also related to two other projects: LÄROM, www.uu.se/larom, directed by professor Sverker Lindblad, in which teacher's education in Sweden and Denmark are studied, and The Struggle for Students. The Swedish Field of Higher Education and the Recruitment Strategies of the Institutions, directed by professor Donald Broady, www.skeptron.uu.se

Swedish educations towards health and nursing - part of a social field of higher education As a contribution to the knowledge of Swedish educations towards health and nursing, we shall in this article describe these educations as a part of a social field of higher education. This field is here defined by the social origins of the students see e.g. Bourdieu $(1,2,3,4)$. The concept of a field puts the relations between different educational tracks in focus. In the empirical context of this article, this means that recruitment profiles for nursing educations are compared to those of other educations, such as teaching and medicine. Not surprisingly it turns out that the relations one find are quite systematic. Knowledge of the relations between educations in terms of social recruitment contributes to the understanding of several aspects of the educations in focus, for example their organisational structure and the subject matter studied in courses.

\section{A study mainly of a national register}

The study is based mainly on a national register of all students in higher education during 1997 - 2001, with information about the students' previous studyresults, as well as a large number of variables about their parents. We have also used statistical information from governmental resources, and conducted three interviews with informants to complement publicly available information about the educations. The informants were all nurses in some of the highest positions in a specific education at an old university in Sweden, the chair of the programme, an associate professor, and a newly inaugurated professor in the field of nursing. These informants, all above 50 years' of age, have participated in the nursing education for a long period of time and are, therefore, well oriented.

\section{An approach initiated by Pierre Bourdieu}

Our approach here follows a line of research initiated by the French sociologist Pierre Bourdieu. In Sweden, this tradition is represented for example by Broady $(5,6,7)$ and his team situated at the University of Stockholm and later Uppsala. This sociological approach to educational research was introduced to the Nordic countries by Staf Callewaert at the University of Copenhagen, see Callewaert (8, $9,10,11)$, Munk $(12,13)$, and Petersen $(14,15)$.

The field of nursing - its history and recent transformations is tightly intertwined with the field of medicine $(16,17)$. Until recently, the curriculum of the nursing education has by and large been defined by medicine. Nursing has been constituted as a dominated part of the field of medicine, which has determined what is needed to become a nurse and defined the working conditions of nurses $(18,19)$.

To define a field of nursing independent of the field of medicine Since the formal inclusion of nursing in the system of higher education in Sweden (in 1977) there has been an ongoing shift towards social science in the content of these educations (20, 21, 22, 23), see also Rooke, (24), Granum, (25) and Friberg (26). This shift is also visible in the curricula for nursing educations. See e.g. curriculum at the University of Uppsala where nursing education is defined as: 60 point/week of Nursing Science, 40points/weeks of Medical Science and 20points/weeks of Social Science. The process can be understood as an attempt by nurses holding higher positions to define a field of nursing, independent of the field of medicine, in terms of its scientific basis as well as its institutional organisation. The content of this new field has recently been discussed by the nursing organisations under the title: Nursing as a scientific discipline or fundamental research - something for Nursing? $(27,28)$. One goal of the study on which this paper is based is to complement these discussions by empirical support for a «field of nursing educations».

A field of nursing educations? The central issue at stake is of course not the independence per se, but the hierarchical distance between nurses and physicians. Has this distance decreased during the last decades or not? We will show that as regards the social origin of the students on these educations, it has probably not decreased very much. To the contrary, a major thesis in this article is that the hierarchical aspect of the relation between nursing and medicine is quite stable. This is in spite of the massive transformations of the curriculum of nursing education and the growth of Caring as a field of research (29). In relation to the field of higher education, nursing educations as well as medical education occupy quite distinct and remote positions. 


\section{Nursing in the field of higher education}

The main characteristic of the recruitment to nursing educations is the high proportion of women, and a general lack of symbolic capital (here measured by social origin). For an introduction to the concept of symbolic capital, as well as other aspects of the sociology of Pierre Bourdieu see (2). All nursing educations in our material have more than $80 \%$ women, and only about $15 \%$ of the students have upper middle class parents. In general, the differences as regards these characteristics (proportion of women and social origin) is quite small between nursing educations. In figure 1 nursing educations are situated in the field of higher education. This visualisation is a scatterplots of proportions, not a correspondence analysis as is common practice in the tradition initiated by Bourdieu. Despite huge differences in mathematical machinery, the graphical results are similar. We prefer scatterplots because of their obvious interpretation, along with some technical problems regarding stability which must be handled when correspondence analysis is applied to the kind of empirical material on which this article is based. As can be seen in the figure, all nursing educations are firmly located in the bottom left corner, displaying their comparatively homogenous recruitment of more women than men, and a lower proportion of students with upper middle class background than in higher education in general.

\section{No systematic differences}

between nursing educations

With few exceptions, variations between sites of education are so small, that they are difficult to interpret. Three such exceptions are Röda Korsets Högskola, Ersta Sköndal högskola and Sophia- hemmets Högskola. These colleges are special in that they are old, and have a history as economically quite wealthy nursing institutions with traditions. We believe this might explain the slightly higher proportion of upper middle class students at Sophiahemmet and Röda Korset, as well as the unusually high proportion of women at Sophiahemmet and Ersta Sköndal.

\section{Nursing educations similar to} teacher educations

As regards these aspects of the recruitment, nursing educations are very similar to teacher educations, especially those specialized for teaching of younger children, which also mostly recruit women with a modest social origin. One may hypothesize that this similarity in position can be used as an explaining factor for some other affinities, regarding e.g. the recurring organisational reforms that these two groups of

\section{Figure 1. Stylized picture of the field of higher education in Sweden 2001. Each gray sym- bol represents a study-program at a particular site of education. The horisontal positions are given by the proportion of male students, and the vertical positions are given by the proportion of students with at least one parent defined as upper middle class. The four rectangles show the principal distribution of study-programs in the areas of caring, educa- tion, medicine and technology.}

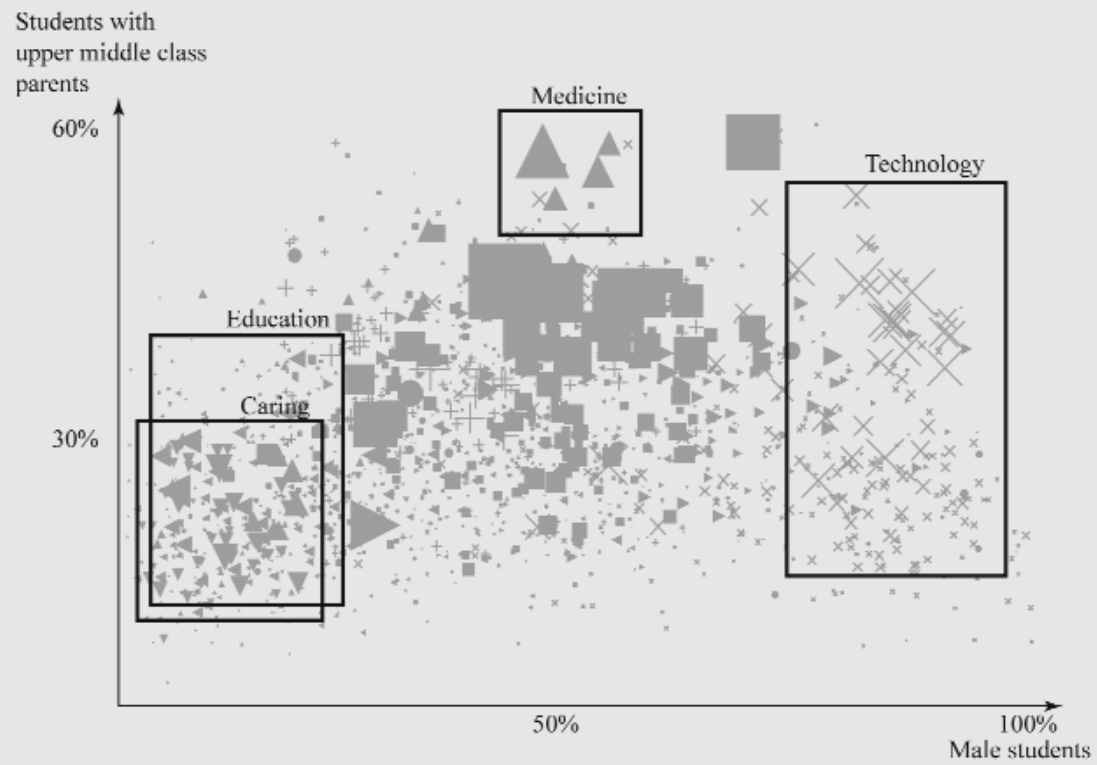

educations have been subjected to.

The figure shows that the teacher educations has a more varied recruitment than nursing educations. This variation is not random; it is connected to an internal hierarchy among the teaching educations. Educations for upper secondary teaching generally recruit more men and more students from the upper middle class, while the opposite is true for educations for preschool teaching see Börjesson, (30), for a discussion.

Jobs with a high proportion of women tend to require increasingly more schooling.

Technical educations are located in the right side in figure 1. Even though the recruitment to these educations is much skewed as regards gender, they recruit a relatively high proportion of students from upper middle class. An explanation of this might be that men with modest social origin and modest school capital quite often find a job right after finishing upper secondary education. In contrast to this, jobs with a high proportion of women tend to require increasingly more schooling.

Physicians an «elite» social group

Several studies of education in Sweden have established physicians as an «elite» social group. This is clearly reflected in these educations' high vertical positions in Figure 1. Approximately as many men as women become physicians, which is usual for educations that recruit a high proportion of students from the upper middle class (this makes the shape of the cloud of points in figure 1 somewhat triangular). There is a large distance between nursing educations and medical educations, despite their affinities regarding subject matter. This can be regarded as a visualisation of the social aspect of the consecra- 


\section{Table 1. Hypotheses regarding factors influencing the recruitment to nursing educations at large sites of education, compared to small sites of education.}

\section{Promoting high recruitment at small sites of education}

Demoting high recruitment at small sites of education

- Lack of attractive alternatives at - Social demography with less the particular University college. proportion upper middle class. - No symbolic domination from - Low status. a medical education.

\section{Far from alternative Universities.}

ted status that physicians have in society (31).

The corresponding relation to nursing educations, compared to that of medical educations

The social recruitment to nursing educations, compared to that of medical educations, shed light on the corresponding relation between nursing science and medicine (32), as well as the power relations in the common workplace (the hospital) of physicians and nurses $(33,34)$.

\section{Recruitment to specific}

educational tracks

The social recruitment to any specific nursing education is the result of many factors that are difficult to quantify, for example the social demography of the site of education, the alternative educati- ons at the site of education, the specific characteristics of the nursing education, its reputation etc. For example, the University of Stockholm is very large, and offers many alternative educational possibilities, and Stockholm has a social demography characterized by a high proportion of upper middle class. This can be contrasted with the University of Gävle, which has relatively few educations to offer, especially none with a high proportion of students with upper middle class parents, and a social demography quite opposite to that of the Stockholm region. Despite these differences, the social recruitment to nursing educations in Stockholm and Gävle is strikingly similar. We hypothesize that this may be due to different factors affecting the social recruitment

Table 2. Age distribution on the specializations of the nursing educations, 1998.

\begin{tabular}{|l|r|r|r|r|r|}
\hline N & $\mathbf{- 2 1}$ & $\mathbf{2 2 - 2 4}$ & $\mathbf{2 5 - 2 9}$ & $\mathbf{3 0 - 3 4}$ \\
\hline Nurse Exam Educ. & $\mathbf{1 5 4 6 2}$ & $26,5 \%$ & $30,3 \%$ & $26,9 \%$ & $16,3 \%$ \\
\hline Childrens care & $\mathbf{8 8}$ & 0 & $12,5 \%$ & $42,0 \%$ & $45,5 \%$ \\
\hline Midwife & $\mathbf{3 9 9}$ & 0 & $5,8 \%$ & $46,1 \%$ & $48,1 \%$ \\
\hline District nurses & $\mathbf{1 7 4}$ & 0 & $5,2 \%$ & $28,2 \%$ & $66,7 \%$ \\
\hline Health and Caring & $\mathbf{1 4 6}$ & 0 & $7,5 \%$ & $44,5 \%$ & $47,9 \%$ \\
\hline Operation theatres & $\mathbf{2 7 9}$ & 0 & $11,8 \%$ & $51,3 \%$ & $36,9 \%$ \\
\hline Psychiatry & $\mathbf{6 1}$ & 0 & $6,6 \%$ & $42,6 \%$ & $49,2 \%$ \\
\hline E-rays & $\mathbf{1 3 6}$ & $16,2 \%$ & $25,7 \%$ & $29,4 \%$ & $28,7 \%$ \\
\hline Older peoples care & $\mathbf{1 3}$ & 0 & 0 & $38,5 \%$ & $61,5 \%$ \\
\hline
\end{tabular}

cancelling out. Some such factors are listed in table 1 . Not knowing the actual effect of them, one can only conclude that nursing educations in Gävle and in Stockholm have quite similar recruitment profiles

\section{No hierarchical structure in} specialization among the nursing education?

Is there a hierarchical structure in specializations among the nursing education? Teachers in the field of nursing would probably answer yes to this question. However, no such hierarchy can be established based on the empirical material available in this study. This may be due to limitations in the data. Instead the most obvious differences that can be observed regard the age of the students, as can be seen in table 2 .

It might first be noted that even though the basic nursing education recruit younger students than the specializations, the age of the students in the nursing education are generally higher than those in most higher educations in Sweden. Education and work are tightly intertwined for nurses, with many students having worked for several years before entering any specific education - of which most can actually be seen as an In Service Training rather than a regular university course. The specialization towards district nurses and older peoples care mainly attract older students, while the students at x-ray units and the operational theatre are younger. Unfortunately the empirical material is such that it is difficult to compare the social recruitment of educations with different age-structure. It is therefore difficult to compare e. $\mathrm{g}$. the basic nurse education with the specialisations, and the specialisations with each other. This might even be the reason why we do not find the expected hierarchical differences, e.g. more students from upper middle class in midwifery, x-rays and operational theatres.

\section{Relation to other educations}

The position of nursing educations in the field of higher education can be further expounded by direct comparisons to other educations (noting the drawback of not taking variations between sites of education into account). In Figure 2 a comparison is made of the students' grades from secondary education. At the time when these data were collected, the grade system was group referenced, with the highest grade being 5 , and the lowest 1 .

This makes the difference between nursing and medicine clearly visible, with civil engineering and law being close to medicine, and preschool teaching being close to nursing. Grades from secondary education are generally correlated to social origin, but the differences between educations are even more accentuated looking at the recruitment of students with high grades.

Grades used as a sorting criterion

This can be explained by the fact that these grades are often used as a sorting criterion among applicants. The differences are largest for the highest grades, because only these can be used to gain access to the sough for educations, such as the medical education. Students with lower grades, which are represented at all educations, have generally been accepted on other grounds than grades, e.g. Swedish Scholastic Aptitude Test, SweSAT, work experience or previous studies. Application to higher education are organized so, that the available places are divided into number of groups, for which different sorting criterion applies. Most students are in the group sorted according to grades from secondary education. Second largest is a group sorted according to 
Figure 2. Grades from upper secondary education for nursing educations compared with some other educations, 1998.

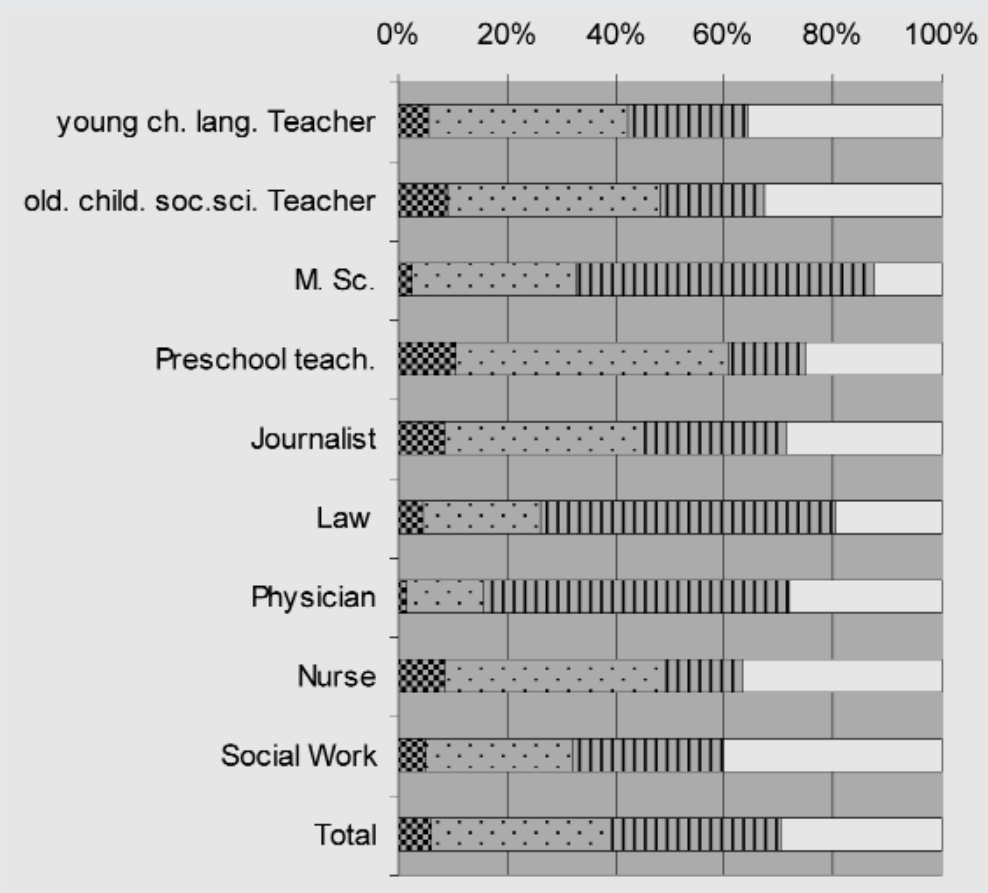

ted sociologically in relation to the structure of the field of higher education. The area of caring, in which the nursing education is so central, is a subordinated position in the field, which means that the education to a large extent is constituted as a lesser prestigious alternative for students that (for one reason or another) were not accepted to the more sought after educations they would preferred to have studied. The recruitment is hence constituted by the existence of competing educations and the principles regulating admission to them.

A «dominated entry» to the field of medicine - impossible for a nurse to achieve high status As a concluding remark, and a suggestion for further study, we want to propose a hypothesis regarding the effects of the nursing examination. We believe that a central mechanism constituting the nursing education as subordinated in relation to medicine is that the exam functions as a kind of «dominated entry» to the field of medicine, as a counterpart to the dominating positions of the physicians. That is, we believe that the process of entrance, the type of consecration, so to speak, that allows you to work in the field of medicine - either as a nurse, or as a physician - is important in constituting the field as fundamentally bipolar, in its distribution of practices as well as in the way it is apprehended, both from inside and outside. E. g. it seems to be quite impossible for a nurse to achieve as high a status as any physician, without taking a regular medical education and becoming a physician herself.

To strengthen the position of nursing is a double-edged sword Reforms aiming to strengthen the position of nursing by reinforcing its status as a profession different from medicine are therefore double-edged swords, since they reinforce the bipolarity of the of the academisation and professionalisation, in general follo- wing large scale trends in society. tion to describe it as a strictly the beginning of these processes at least from the middle of 1920 processes affect power relations more specifically, the relation of dominance between medicine and ursing? Given the great difficullonger periods of time, this study never the less highlights the fact that there is a profound gap between nursing and medicine in terms of the recruitment of students. If you view higher education as a space, the distance between nursing and medicine is very large. The hierarchical differences between the medical profession and the nursing profession as regards social status, salaries and authority in hospitals (or the place at work in general), are it was not possible to construct a sociologically meaningful space of nursing educations. To the contrary, it is quite clear that nursing educations have quite similar recruitment in comparison with the total field of higher education in Sweden. If one tentatively assumes that the differences between nursing educations are relatively small, this can be interpre- 
field and thus make the symbolic gap between physicians and nurses even larger. The aim is of course that this gap should be «horizontal» rather then hierarchical, but one might argue that another way to strengthen the position of nursing not yet pursued would be to fight more explicitly against the bipolarity itself in the field of medicine. Quite contrary to being a resource for achieving higher status, we therefore tentatively claim that the title as a nurse also make the relation of domination towards medicine more clear cut and therefore contributes to its reproduction (4).

Accepted for publication 1 . February 2007

Karin Anna Petersen, lektor, docent,

Pedagogiska institutionen,

Uppsala universitet

Box 2109, SE 75002 Uppsala,

Telefon: +46- (0)18-471 1608

Cellphone: +45 2381 5520,

www.ped.uu.se

karin.anna.petersen@ped.uu.se and

professor (gäst), högskolan Kristianstad,

Se-291 88 Kristianstad, Direkte tfn: + 46 (0) 44-20 40 56, Hus 5211,karin_anna.petersen@hkr.se

Sverker Lundin, doktorand, Pedagogiska institutionen, Uppsala universitet

Box 2109, 75002 Uppsala, Besöksadress: Sturegatan 4B, Telefon: +46-

Webmail: Sverker Lundin <sverker.lundin@gmail.com> Lorensbergsgatan 841136 GÖTEBORG, +47 (0) 706047095; +46 (0) 31544518

\section{References}

1. Bourdieu, P. Distinction. A social critique of the judgement of taste. London and New York: Routledge \& Kegan Paul; 1979.
2. Bourdieu, P. The forms of Capital, In: Richardson, John G. (ed.): Handbook of Theory and Research for the Sociology of Education. Greenwood Press; 1986.

3. Bourdieu, P. La Nobless d'état. Grandes ecoiles et esprit de corps Paris: Les Editions de minuit;1989.

4. Bourdieu, P, Passeron, J-C. Reproduction in Education, Society and Culture. London, Newbury Park, New Delhi: Sage publications; 1990.

5. Broady, D, Lundgren UP. Skeptron 1.Tema: Rätten att tala.Stockholm: Symposium Bokförlag; 1984

6. Broady, D. Sociologi och epistemologi om Pierre Bourdiues författerskap och den historiska epistemologin. Stockholm: HLS, Förlag; 1990.

7. Broady, D.Kulturens fält - en antologi. Göteborg: Daidalos; 1998.

8. Berner, B, Callewaert S, Silberbrandt H. Skole, ideologi og samfund. København: Munksgaard, Uddannelsesforlaget; 1977.

9. Berner, B, Callewaert S, Silberbrandt H.Uddannelse og bevidsthed. København: Munksgaard, Uddannelsesforlaget.

10. Callewaert, S.Kultur, pædagogik og videnskab. Om Pierre Bourdieus habitusbegreb og praktikteori. København: Akademisk forlag; 1992.

11. Callewaert, S: Fra Bourdieus og Foucaults verden - pædagogik og sociologi, diskurser og praktikker, efter det moderne. København: Akademisk Tid \&Tanke; 2003.

12. Munk, M. Livsbaner gennem et felt. Lund: Lunds Universitet; Sociologiska institutionen; 1999.

13. Munk, M.Idrættens kulturelle pol. En analyse af idrætsfeltets autonomi belyst ved Pierre Bourdieus metode. København: Museum Tusculanums Forlag; 2004
14. Petersen, KA. Sygeplejevidenskab - myte eller virkelighed? Om genese og struktur af feltet af akademiske uddannelser og forskning i sygepleje i Danmark, Afhandling, Bilag Del I, Bilag Del II.Viborg: Viborg Amt, Centre for videregående uddannelser, CVU; 1999.

15. Petersen, KA, Høyen M, Åberg A A Study of life trajectories at two Nursing Schools In: Petersen, K. et al. Network society and the demand of educational changes. Uppsala: Pedagogiska Institutionen, Uppsala Universitet; 2003.

16. Halskov, G.Sygeplejediagnoser det medicinske felts sprog og logikker? In: Jørgensen, EB. Sundhedsvidenskabelige praktikker. Et bud på fagindhold for medicinsk humaniora. København: Akademisk Forlag; 1996.

17. Halskov, G. Professionalisering og/eller videnskabeliggørelse? In: Jørgensen, EB. Sundhedsvidenskabelige praktikker. Et bud på fagindhold for medicinsk humaniora. Akademisk Forlag; 1996.

18. Petersen, KA. At studere sygepleje - på vej mod en professions didaktik. In: FASID, København: Akademiske sygeplejersker; 2001:6;37-60.

19. Petersen, KA. Sygepleje - sygeplejeforskning - fra plejeassistent til forskningsassistent eller teoretisk empirisk forsker om sygepleje. In: FASID, København: Akademiske sygeplejersker; 2003b; 40-63.

20. Heyman, I. Gånge hatt till... Omvårdnadsforskningens framväxt i Sverige - sjuksköterskors avhandlingar 1974-1991. Göteborg: Daidalos; 1995.

21. Petersen, KA. Praktikteori i sundhedsvidenskab. København: Akademisk forlag; 1995.

22. Petersen, KA. Praktikker i erhver og uddannelse. København, Akademisk; 2001

23. Jørgensen, EB. Sundhedsvidenskabelige praktikker. Et bud på fagindhold for medicinsk humaniora. København: Akademisk Forlag; 1996.

24. Rooke, L. Omvårdnad. Teoretiska ansatser i praktisk verksamhet. Stockholm: Liber; 1995.

25. Granum, V. Studenternes forestillinger om sygepleje som fag og funksjon. Göteborg: Göteborg Studies in Educational Sciences Göteborg 2001; 164.

26. Friberg, F. Pedagogiska möten mellan patienter och sjuksköterskor på en medicinsk vårdavdeling. Mot en vårdidaktik på livsvärldsgrund, Göteborg: Göteborg Studies in Educational Sciences, Göteborg; 2001; 170 .

27. Lehtinen, U, Öhlén J, Asplund K. Grundforskning-något för omvårdnad?Svensk Sjuksköterskeförening 1910, Stockholm; 2002

28. Östlinder, G. Omvårdnad som akademiskt ämne i forskning, utbildning och patientnära verksamhet svensk Sjuksköterskeförening 1910, Stockholm; 2002.

29. Ahlgren I.,Gummesson A.Utbildningsplaner och reformimplementering. Sjüksköterskeutbildningen i fokus. Uppsala: Acta Universitatis Upsaliensis, Uppsala Studies in Education 87; 2000; 87

30. Börjesson, M. Det svenska högskolefältet och lärarutbildningarna, Uppsala: Forskningsgruppen för utbildnings- och kultursociologi; 2003.

31. Bourdieu, P.Homo Academicus. Stockholm: Brutus Östlings Bokförlag, Symposium; 1996.

32. Callewaert, S. Fra Bourdieus og Foucaults verden. Pædagogik og sociologi, diskurser og praktikker efter det moderne. København: Akademisk, Tid\&tanke; 2003.

33. Foucault, M.Overvågning og straf, Frederiksberg: Redaktion Filosofi, Det Lille Forlag; 1994

34. Foucault, M.Klinikkens fødsel. København: Hans Reitzels Forlag; 2000 . 